\title{
RESULTS OF MONITORING OF THE POPULATION OF Blumeria graminis f.sp. hordei IN LATVIA IN 2009-2010
}

\author{
Inese Kokina* and Isaak Rashal** \\ * Daugavpils University, Institute of Systematic Biology, Vienības 13, Daugavpils, LV 5401, LATVIA \\ inese.kokina@ biology.lv \\ ** Institute of Biology, University of Latvia, Salaspils, Miera iela 3, LV-2169, LATVIA \\ izaks@email.lubi.edu.Iv
}

Contributed by Isaak Rashal

\begin{abstract}
In 2009-2010, random samples of the causal agent of barley powdery mildew were collected in Daugavpils (south-eastern Latvia, Latgale region), Stende (north-western Latvia, Kurzeme region) and Priekuli (north-eastern Latvia, Vidzeme region). Virulence frequency, complexity and pathotypes were calculated in the pathogen populations. Significant differences of virulence detected by the genes Va1, Va3 and Va13 occurred among samples of the pathogen population collected in different parts of Latvia. Nei index, Müller's index, Kosman index, Shannon index and Simpson index showed considerably higher diversity in Daugavpils and Stende during 2009-2010. In Daugavpils, the population of Blumeria graminis f.sp. hordei was particularly characterised by high diversity.
\end{abstract}

Key words: Blumeria graminis f.sp. hordei, barley, virulence, resistance, complexity, pathotype.

\section{INTRODUCTION}

Barley (Hordeum vulgare L.) has played a pivotal role in Old World agriculture since its domestication about 10000 years ago (Piffanelli et al., 2004) and is the fourth most important cereal crop in the world, after wheat, maize and rice (Czembor, 2001; Anonymous, 2009b). Barley is also one of the most important cereals in Latvia. In 2008, the area of sown spring barley was $28 \%$ (147 $000 \mathrm{ha}$ ) of the total cereal area in Latvia (Anonymous, 2009a). In 2009, of the area of barley decreased to 104700 ha (Anonymous, 2009b).

The causal agent of barley powdery mildew, Blumeria graminis DC. f.sp. hordei Ėm. Marchal, is a windborne, biotrophic, fungal pathogen of cultivated and wild barley. It is particularly prevalent under cool conditions when the maximum daily temperature does not exceed $25{ }^{\circ} \mathrm{C}$ (Dreiseitl et al., 2006). Powdery mildew is one of the most destructive foliar diseases of barley in regions such as Europe (Czembor, 2001). In Latvia, where the climate is moderate, the pathogen develops in two stages: in the vegetation period, numerous conidia are formed, which ensure propagation and dispersal of the fungi; in autumn, cleistothecia with spores are formed on senescing parts of plants. The spores mature in the next spring and cause host infection, and powdery mildew epidemics.

Presently, powdery mildew-barley genetic interactions are considered as one of the host-pathogen systems that is well genetically characterised (McDermott et al., 1994). Harold Henry Flor proposed a gene-for-gene model for the genetic interaction between plant and pathogen, in which a dominant gene of the host interacts with a corresponding dominant virulence gene of the pathogen. Interactions between the two corresponding genes, the host resistance gene and the pathogen avirulence gene, induce a hypersensitive response, in this way providing resistance. Tools of molecular biology led to a hypothesis that a ligand from the pathogen interacts with a corresponding plant receptor, which triggers a defence response (Richter and Ronald, 2000).

More than 100 mildew resistance genes have been identified in barley cultivars, landraces, and wild or related Hordeum species. Mlg was the first gene introduced on a large scale in the $20^{\text {th }}$ century (Brown and Jørgensen, 1991; Czembor, 2001). Many mildew resistance alleles have been identified on chromosome $4 \mathrm{H}$ and chromosome $1 \mathrm{H}$ of the barley genome. The Mla locus for barley resistance to powdery mildew is located on chromosome $1 \mathrm{H}$ (Schüller et al., 1992). Most genes in the Mla locus have lost their effectiveness during the recent few years in different regions of $\mathrm{Eu}-$ rope, due to the high level of pathogenic variability of powdery mildew (Müller et al., 1996; Caffier et al., 1999; Limpert et al., 1999; Hovmøller et al., 2000; Dreiseitl, 2004a; 2004b; 2008; Kokina and Rashal, 2005a; 2007; 2012). Most of the powdery mildew resistance genes, including Mla1, Mla3, Mla6, Mla7, Mla9, Mla12, Mla13, Mlat, Mlk, Mlg, Mlh and Mlra, are commercially derived from the Mediterranean region (Czembor, 2001). Barley plants carrying recessive alleles of the Mlo locus are resis- 
tant against all known isolates of powdery mildew fungus (Jørgensen, 1992; Piffanelli et al., 2004).

Host-pathogen evolution has has been a driver of biological diversity (Laine, 2006). The evolution of virulence involves the emergence of pathogens, host switch and host range expansion, and overcoming of host resistance, which may compromise the success of control strategies for diseases. Virulence evolution has an important role of pathogens in ecosystem composition and dynamics (Sacristán and Garcia-Arenal, 2008) and is considered as a force influencing diversity, including resistance, in plants (Brown, 2003). Genetic polymorphism of resistance in the host reduces the probability that a parasite infects the host (Thrall and Burdon, 2003).

There has been increased interest in the structure of Blumeria graminis f.sp. hordei local populations, because understanding the evolution of the pathogen requires recognition of variation within and between populations (Müller $e t$ al., 1996). Moreover, individual genetic structures for local populations of typical air-borne pathogens like the causal agent of barley powdery mildew can differ greatly from the average structure of aerial population (Dreiseitl and Wang, 2007). The evolutionary potential of the pathogen population influences the durability of disease resistance.

The overall goal of this study was to characterise the $B$. graminis f.sp. hordei population in Latvia. The specific objectives were: 1) to characterise the population in Latvia using standard European differentials supplemented by barley lines with "new" resistance genes; 2) to compare virulence frequencies, complexity and pathotypes, defined as combinations of virulences, on a set of differential hosts carrying different resistance genes, in samples collected in different parts of Latvia; 3) to evaluate the diversity and evolution potential of the population for further use in the barley breeding programme for resistance.

\section{MATERIAL AND METHODS}

Pathogen population and sampling. In 2009-2010, random samples of Blumeria graminis f.sp. hordei isolates were obtained in three regions of Latvia. Among the sampling sites were commercial barley fields near Daugavpils (south-eastern part of Latvia, Latgale region), where samples were collected both in conidia and cleistothecia stages from unknown host genotypes in 2009-2010. Samples in conidia were collected before peak powdery mildew development. In the second sampling site, located near Talsi (north-western part of Latvia, Kurzeme region), samples of the pathogen were collected in breeding fields of the State Stende Cereal Breeding Institute, only in the cleistothecia stage in both years of investigation, from five barley varieties ('Annabell' and 'Druvis' in 2009 and 'Dzintara', 'Agra', 'Austris' and 'Druvis' in 2010). In the third sampling site, located in Priekuli (north-eastern part of Latvia, Vidzeme region), pathogen samples were collected in breeding fields of the State Priekuli Plant Breeding Institute in the cleistothecia stage from barley varieties 'Agra' and 'Rolfi'in 2009. The distance between Daugavpils and Stende is about $350 \mathrm{~km}$, between Daugavpils and Priekuli about $210 \mathrm{~km}$, and between Stende and Priekuli about 200 $\mathrm{km}$. Dates and location of the sampling are presented in Table 1 .

Isolation and multiplication of single colonies. For isolation and multiplication of single colonies from samples, both in conidia and cleistothecia, the first leaves of the universally susceptible barley variety 'Otra' were used. Plants were grown in a pot with soil at temperature $18-20{ }^{\circ} \mathrm{C}$ (12 h) under artificial light for 7-10 days.

Leaf segments of the host with single colonies of the pathogen that had developed from natural infections were placed in $100 \mathrm{~mm}$ plastic Petri dishes with $1 \%$ water agar and $0.004 \%$ benzimidazole and incubated for $20-24 \mathrm{~h}$ at 22

Table 1

BARLEY POWDERY MILDEW SAMPLES COLLECTED IN LATVIA IN 2009-2010

\begin{tabular}{|c|c|c|c|c|c|c|}
\hline Location & Sampling year & Date of sampling & $\begin{array}{l}\text { Barley } \\
\text { genotype }\end{array}$ & $\begin{array}{l}\text { Number of tested } \\
\text { isolates }\end{array}$ & $\begin{array}{l}\text { Life cycle stage of the pathogen } \\
\text { (conidia or cleistothecia) }\end{array}$ & ID \\
\hline \multirow[t]{4}{*}{ Daugavpils } & 2009 & June 28 & unknown & 40 & conidia & $\mathrm{Da} / 09 / \mathrm{con}$ \\
\hline & & July 29 & unknown & 40 & cleistothecia & $\mathrm{Da} / 09 / \mathrm{cl}$ \\
\hline & 2010 & June 28 & unknown & 40 & conidia & $\mathrm{Da} / 10 / \mathrm{con}$ \\
\hline & & August 5 & unknown & 40 & cleistothecia & $\mathrm{Da} / 10 / \mathrm{cl}$ \\
\hline \multirow[t]{8}{*}{ Stende } & 2009 & July 25 & 'Regatta' & 21 & cleistothecia & $\mathrm{St} / 09 / \mathrm{cl} / 1$ \\
\hline & & July 25 & 'Annabell' & 21 & cleistothecia & $\mathrm{St} / 09 / \mathrm{cl} / 2$ \\
\hline & & July 25 & 'Druvis' & 20 & cleistothecia & $\mathrm{St} / 09 / \mathrm{cl} / 3$ \\
\hline & & July 25 & 'Idumeja' & 20 & cleistothecia & $\mathrm{St} / 09 / \mathrm{cl} / 4$ \\
\hline & & July 25 & 'Merbin' & 21 & cleistothecia & $\mathrm{St} / 09 / \mathrm{cl} / 5$ \\
\hline & 2010 & August 5 & 'Dzintara' & 31 & cleistothecia & $\mathrm{St} / 10 / \mathrm{cl} / 1$ \\
\hline & & August 5 & 'Agra' & 23 & cleistothecia & $\mathrm{St} / 10 / \mathrm{cl} / 2$ \\
\hline & & August 5 & 'Druvis' & 24 & cleistothecia & $\mathrm{St} / 10 / \mathrm{cl} / 4$ \\
\hline \multirow[t]{2}{*}{ Priekuḷi } & 2009 & August 18 & 'Agra' & 30 & cleistothecia & $\mathrm{Pr} / 09 / \mathrm{cl} / 1$ \\
\hline & & August 14 & 'Rolfi' & 30 & cleistothecia & $\mathrm{Pr} / 09 / \mathrm{cl} / 2$ \\
\hline
\end{tabular}


$24{ }^{\circ} \mathrm{C}$. Well-developed monopustules were transferred onto $25 \mathrm{~mm}$ long healthy primary leaves of 'Otra', which were placed on $1 \%$ water agar in Petri dishes and incubated at $18-20{ }^{\circ} \mathrm{C}(12 \mathrm{~h})$ under artificial light for ten days.

For isolation of ascospores from cleistothecia, the host leaf segments with well-developed cleistothecia were placed on wet filter paper on the lid of a Petri plate and cultivated at $18-20{ }^{\circ} \mathrm{C}$ for $3-4$ days. Then, the lids with mature cleistithecia were placed in Petri plates with 'Otra' 20-mm leaf segments on $1 \%$ water agar with $0.004 \%$ benzimidazole. When the filter paper had dried out, cleistothecia contracted and „shot" ascospores, infecting the host leaves. Host leaves infected by ascospores were incubated at $18-20{ }^{\circ} \mathrm{C}$ for $3-4$ days and used for isolation of single colonies.

Inoculation of differentials. For testing of single colonies, the set of used differentials (Kølster et al., 1986) comprised nine near-isogenic Pallas lines, barley line SII and three barley varieties 'Steffi', 'Goldie' and 'Meltan', which contained different genes for resistance to powdery mildew. Monopustule isolates were also tested on mlo 5 (near isogenic Pallas line P22). A list of differentials used for detection of virulence genes in the population of Blumeria graminis f.sp. hordei in Latvia in 2009-2010 is presented in Table 2.

About 50-70 seeds of each differential were sown in plastic pots with sandy soil and were grown under laboratory conditions at $18-20{ }^{\circ} \mathrm{C}$ and natural light $10-14$ days until well-developed first leaves appeared. Leaf segments with length approximately $20 \mathrm{~mm}$ were cut and placed on water agar with $0.004 \%$ benzimidazole in Petri dishes $(100 \mathrm{~mm}$ in diameter). The number of Petri dishes was identical with the number of tested isolates.

Inoculation of differentials was conducted according by microinoculation (Dreiseitl, 1998). Monopustule isolates were drawn into a micropipette and dispensed into a setting tower, under which differentials $1 \%$ water agar with $0.004 \%$ benzimidazole in a Petri plate were exposed. The plates with inoculated differentials were incubated in chambers at temperature $18-20{ }^{\circ} \mathrm{C}$ in light with a photoperiod of $12 \mathrm{~h}$.

Table 2

DIFFERENTIALS USED FOR DETECTION OF VIRULENCE GENES IN Blumeria graminis f.sp. hordei SAMPLES COLLECTED IN LATVIA IN 2009-2010

\begin{tabular}{ll}
\hline \multicolumn{1}{c}{ Differentials } & \multicolumn{1}{c}{ Main resistance genes } \\
\hline P01 & Mla1 \\
P02 & Mla3 \\
P03 & Mla6 \\
P04B & Mla7 \\
P08B & Mla9 \\
P10 & Mla12 \\
P11 & Mla13 \\
P17 & Mlk \\
P23 & MlLa \\
SI1 & Ml(SI) \\
'Steffi' & Ml(St1), Ml(St2) \\
'Goldie' & Mla12, MlLa, U \\
'Meltan' & Mla13, Ml(Im9), Ml(Hu4)
\end{tabular}

Virulence determination. The infection type of differentials was detected 7-8 days after inoculation, according to a 0-4 point scale (Torp et al., 1978). Isolates with reaction type $0-3$ were classified as resistant. Reaction type 4 was considered virulent on the corresponding resistance genes. Virulence frequencies, complexity (virulence gene number per genotype) and combinations of virulence genes in isolates were detected by pooling individual isolates from corresponding samples. Each pathotype was designated by the set of virulence genes present in a particular isolate.

Data analysis. Virulence frequency, complexity and pathotypes were calculated with the programme RASA. For characterisation of the diversity within populations and the distance between populations, Kosman indices were used (Kosman and Leonard, 2007). All diversity parameters were computed using the KOIND package (Kosman, 2002), which are based on the bootstrap method. Statistical significance of differences between all calculated parameters, including Kosman diversity $\mathrm{KW}$ and distance $\mathrm{KB}$, were evaluated using the Student t-test at $\alpha=0.05$.

\section{RESULTS}

Virulence frequency. In 2009-2010, 425 single isolates of the causal agent of barley powdery mildew, collected in different parts of Latvia, were tested on 13 differentials. Frequencies of virulence genes found in different parts of Latvia are presented in Table 3. In both years, no virulences were found against resistance genes from $S I 1$ and against mlo5. In contrast, the frequencies of virulences against the single resistance gene Mla9 and against combined resistance genes Mla6, Mla7, Mlk and Ml(La) were high in both years of investigation in all samples and varied from $60.0 \%$ to $97.0 \%$. In samples collected in Stende, between 2009 and 2010, frequencies of the genes Val, Va3 and Val3 significantly decreased from $40.5 \%$ to $20.0 \%$, from $40.5 \%$ to $18.0 \%$ and from $52.3 \%$ to $24.0 \%$, respectively. In contrast,

Table 3

FREQUENCY OF VIRULENCE GENES (\%) FOUND IN LATVIA IN 2009-2010

\begin{tabular}{l|c|c|c|c|c}
\hline $\begin{array}{c}\text { Virulence } \\
\text { genes }\end{array}$ & $\mathrm{Da} / 09$ & $\mathrm{Da} / 10$ & $\mathrm{St} / 09$ & $\mathrm{St} / 10$ & $\mathrm{Pr} / 09$ \\
\hline Val & 46.2 & 52.5 & 40.5 & 20.0 & 48.3 \\
Va3 & 45.0 & 50.0 & 40.5 & 18.0 & 51.7 \\
Va6 & 71.3 & 70.0 & 94.2 & 86.2 & 85.0 \\
Va7 & 65.0 & 60.0 & 86.0 & 81.4 & 70.0 \\
Va9 & 66.3 & 62.5 & 97.0 & 88.7 & 73.3 \\
Va12 & 75.0 & 72.5 & 65.1 & 55.3 & 83.3 \\
Va13 & 42.5 & 46.3 & 52.3 & 24.0 & 41.6 \\
$V k$ & 78.8 & 78.8 & 86.6 & 82.5 & 76.6 \\
$V($ La $)$ & 83.8 & 81.3 & 71.8 & 64.7 & 75.0 \\
$V(S I)$ & 0.0 & 0.0 & 0.0 & 0.0 & 0.0 \\
$V($ St $)$ & 23.8 & 23.8 & 37.2 & 36.9 & 21.7 \\
$V(G o)$ & 22.5 & 23.8 & 39.1 & 40.8 & 23.3 \\
$V(\mathrm{Me})$ & 20.0 & 20.0 & 39.1 & 39.5 & 28.3
\end{tabular}


increases in frequencies of $\mathrm{Val}$ from $46.2 \%$ to $52.5 \%, \mathrm{Va3}$ from $45.0 \%$ to $50.0 \%$ and Val3 from $42.5 \%$ to $46.3 \%$ were observed in Daugavpils. Virulences from 'Steffi' and 'Goldie' were significantly higher in samples collected in Stende.

Virulence complexity and diversity parameters. The lowest virulence complexity detected in Latvia in 2009-2010 (two virulence genes) was found in one pathotype collected in Daugavpils. The highest virulence complexity represented by 12 virulence genes was found in 11 pathotypes collected in Daugavpils and Stende. In both years of investigation, the mean complexity varied from $6.33 \pm 0.30$ to $10.00 \pm 0.44$. In Daugavpils, a tendency of increasing mean complexity in cleistothecia samples was observed. In 2009-2010, mean complexity of isolates in samples collected on different host genotypes differed between Stende and Priekuli (Table 4). In total, 95 pathotypes were detected in 425 isolates. Among different samples and years, number of pathotypes with frequency more than $5 \%$ varied from 2 to 6 and number of pathotypes per sample from 2 to 27 . The lowest number of pathotypes was detected in the Stende population, while in populations of Daugavpils and Priekuli high numbers of pathotypes were found. The highest richness 0.83 was found in Priekuli in samples collected in 2009 on 'Rolfi', and the lowest 0.09 in Stende in 2009 in samples collected on 'Annabell'

In both years of investigation, the pathotype a7 a9 a12 $\mathrm{k} \mathrm{La}$ was dominant in Daugavpils only. In 2009, pathotypes al a3 a6 a9 a13 k; a6 a7 a9 a12 k la St Go Me and ala3 a6 a7 a9 al2 a13 k La were dominant in Stende. In contrast, in 2010 other pathotypes (a6 a7 a9 St Go Me; a6 a7 a9 St Go Me; a3 al3 k Go and al a3 a6 a7 a9 a12 al3 k la St Go $\mathrm{Me}$ ) had highest frequency (Table 5). The pathotype al a3 al3 were detected in Daugavpils only. During 2009-2010, a clear tendency to increasing of richness was observed in isolates from Stende.

Nei index, Müller's index, Kosman index, Shannon index and Simpson indexes showed higher diversity in Daugavpils and Stende during 2009-2010 (Table 6). In 2009, the Kosman distance between Daugavpils and Priekul,i populations was 0.102, between Daugavpils and Stende 0.215 and between Stende and Priekuli - 0.190. In 2010, a higher Kosman distance (0.304) between Daugavpils and Stende was observed. A significant Kosman distance (0.318) between years of investigation was observed in Stende, but was low (0.101) in Daugavpils. The genetic distances between populations in 2009 and 2010 was 0.159 (Table 7).

\section{DISCUSSION}

Local populations of Blumeria graminis f.sp. hordei can change due to mutation, migration, recombination and direct selection, and therefore new dangerous pathotypes spread rapidly (Dreiseitl, 2000). In Latvia, evaluation of virulence was begun in 1981, which was the first study of this kind in the Baltic States. Until 1994, observations were carried out only in the central part of Latvia (Rashal and Tueryapina, 1996; Tueryapina et al., 1997). Since 1995, a regular study of the genetic structure of the pathogen was conducted in the south-eastern part of Latvia, in the Latgale region (Kokina and Rashal, 2004; 2005a; 2005b; 2007; 2008). The pathogen had not been studied previously in other parts of the country and there were no available data on virulence frequencies, distribution, complexity and pathotypes, although in Latvia, there are many domestic and foreign varieties grown.

COMPARISON OF DIFFERENT POPULATIONS OF Blumeria graminis f.sp. hordei IN LATVIA IN $2009-2010$

\begin{tabular}{|c|c|c|c|c|c|c|c|c|c|c|c|c|c|c|c|}
\hline Parameter & $\begin{array}{c}\mathrm{Da} / 09 / \\
\text { con }\end{array}$ & $\begin{array}{c}\mathrm{Da} / 09 / \\
\mathrm{cl}\end{array}$ & $\begin{array}{c}\mathrm{Da} / 10 / \\
\text { con }\end{array}$ & $\begin{array}{c}\mathrm{Da} / 10 / \\
\mathrm{cl}\end{array}$ & $\begin{array}{c}\mathrm{St} / 09 / \\
\mathrm{cl} / 1\end{array}$ & $\begin{array}{c}\mathrm{St} / 09 / \\
\mathrm{cl} / 2\end{array}$ & $\begin{array}{c}\mathrm{St} / 09 / \\
\mathrm{cl} / 3\end{array}$ & $\begin{array}{c}\mathrm{St} / 09 / \\
\mathrm{cl} / 4\end{array}$ & $\begin{array}{c}\mathrm{St} / 09 / \\
\mathrm{cl} / 5\end{array}$ & $\begin{array}{c}\mathrm{St} / 10 / \\
\mathrm{cl} / 1\end{array}$ & $\begin{array}{c}\mathrm{St} / 10 / \\
\mathrm{cl} / 2\end{array}$ & $\begin{array}{c}\mathrm{St} / 10 / \\
\mathrm{cl} / 3\end{array}$ & $\begin{array}{c}\mathrm{St} / 10 / \\
\mathrm{cl} / 4\end{array}$ & $\begin{array}{c}\mathrm{Pr} / 09 / \\
\mathrm{cl} / 1\end{array}$ & $\begin{array}{c}\mathrm{Pr} / 09 / \\
\mathrm{cl} / 2\end{array}$ \\
\hline No. of isolates & 40 & 41 & 40 & 40 & 21 & 21 & 20 & 21 & 21 & 31 & 23 & 24 & 24 & 30 & 31 \\
\hline Total number of pathotypes & 27 & 22 & 26 & 24 & 6 & 2 & 2 & 4 & 4 & 10 & 12 & 11 & 12 & 18 & 25 \\
\hline $\begin{array}{l}\text { No. of pathotypes with } \\
\text { frequency higher than } 5 \%\end{array}$ & 3 & 5 & 2 & 5 & 5 & 2 & 2 & 2 & 3 & 4 & 3 & 5 & 6 & 6 & 2 \\
\hline Mean complexity ${ }^{2}$ & $\begin{array}{c}8.00 \\
\pm 0.28\end{array}$ & $\begin{array}{c}9.00 \\
\pm 0.43\end{array}$ & $\begin{array}{l}9.01 \\
\pm 0.25\end{array}$ & $\begin{array}{c}10.00 \pm 0 \\
.44\end{array}$ & $\begin{array}{c}7.33 \\
\pm 0.32\end{array}$ & $\begin{array}{c}7.00 \\
\pm 0.32\end{array}$ & $\begin{array}{c}7.50 \\
\pm 0.34\end{array}$ & $\begin{array}{c}7.80 \\
\pm 0.40\end{array}$ & $\begin{array}{c}7.10 \\
\pm 0.31\end{array}$ & $\begin{array}{c}7.32 \\
\pm 0.23\end{array}$ & $\begin{array}{c}7.35 \\
\pm 0.53\end{array}$ & $\begin{array}{c}6.33 \\
\pm 0.30\end{array}$ & $\begin{array}{c}6.88 \\
\pm 0.41\end{array}$ & $\begin{array}{c}7.86 \\
\pm 0.22\end{array}$ & $\begin{array}{c}8.20 \\
\pm 0.25\end{array}$ \\
\hline $\begin{array}{l}\text { The highest virulence } \\
\text { complexity/number of } \\
\text { isolates } 1\end{array}$ & $9 / 4$ & $12 / 3$ & $9 / 1$ & $12 / 3$ & $9 / 4$ & $9 / 14$ & $9 / 10$ & $9 / 13$ & $9 / 5$ & $9 / 3$ & $12 / 5$ & $9 / 3$ & $10 / 2$ & $9 / 6$ & $9 / 1$ \\
\hline $\begin{array}{l}\text { The lowest virulence } \\
\text { complexity/number of } \\
\text { isolates }\end{array}$ & $2 / 1$ & $3 / 3$ & $3 / 4$ & $3 / 3$ & $3 / 1$ & $6 / 7$ & $6 / 10$ & $3 / 1$ & $3 / 1$ & $3 / 1$ & $5 / 1$ & $3 / 1$ & $5 / 11$ & $5 / 1$ & $4 / 3$ \\
\hline $\begin{array}{l}\text { Frequency of the dominant } \\
\text { pathotype }(\%)\end{array}$ & 25.0 & 12.5 & 22.5 & 12.5 & 28.6 & 66.7 & 50.0 & 65.0 & 52.4 & 45.2 & 30.4 & 20.8 & 20.8 & 20.0 & 16.7 \\
\hline Richness $^{2}$ & 0.67 & 0.55 & 0.65 & 0.60 & 0.28 & 0.09 & 0.10 & 0.20 & 0.20 & 0.32 & 0.52 & 0.45 & 0.5 & 0.60 & 0.83 \\
\hline
\end{tabular}

(number of pathotypes/

number of isolates)

\footnotetext{
${ }^{1}$ different pathotypes were detected in the tested isolates

2 all values for different populations and years were significantly different
} 
DOMINANT PATHOTYPES IN THE POPULATION OF Blumeria graminis f.sp. hordei IN LATVIA IN 2009-2010

\begin{tabular}{|c|c|c|c|c|c|}
\hline \multirow[t]{2}{*}{ Pathotype } & \multicolumn{5}{|c|}{ Number of corresponding isolates } \\
\hline & Da-2009 & Da-2010 & St-2009 & St-2010 & Pr-2009 \\
\hline al a3 a6 a7 a9 al2 k La & & & 6 & 14 & \\
\hline$a 6$ a 7 a9 a12 $\mathrm{kLa}$ & 15 & & & 7 & 11 \\
\hline a6 a7 a9 a13 St Go Me & & & 11 & 5 & \\
\hline a6 a7 a9 St Go Me & & & & 5 & \\
\hline al a3 a 13 k Go & & & & 5 & \\
\hline al a3 a6 a7 a9 a12 al3 k La St Go Me & & & & 5 & \\
\hline al a3 a6 a 9 al3 $k$ & & & 10 & & \\
\hline a6 a 7 a9 a12 k La St Go Me & & & 13 & & \\
\hline al a3 a6 a 7 a 912 a 13 k La & & & 14 & & \\
\hline$a 7$ a9 a12 k La & 5 & 14 & & & \\
\hline
\end{tabular}

Da-09, Daugavpils in 2009; Da-10, Daugavpils in 2010; St-09, Stende in 2009; St-10, Stende in 2010; Pr-09, Priekuḷi in 2009

Table 6

PARAMETERS OF DIVERSITY WITHIN POPULATIONS OF Blumeria graminis f.sp. hordei IN LATVIA IN 2009-2010

\begin{tabular}{lc|c|c|c|c}
\hline \multicolumn{1}{c|}{$\begin{array}{c}\text { Parameter } \\
\text { of diversity }\end{array}$} & Da-2009 & Da-2010 & St-2009 & St-2010 & Pr-2009 \\
\hline $\begin{array}{l}\text { Total number } \\
\text { of isolates }\end{array}$ & 80 & 80 & 103 & 102 & 60 \\
$\begin{array}{l}\text { Nei index } \\
\text { Müller's index }\end{array}$ & 0.374 & 0.384 & 0.341 & 0.355 & 0.350 \\
$\begin{array}{l}\text { Kosman expected } \\
\text { index }\end{array}$ & 0.566 & 0.600 & 0.531 & 0.557 & 0.519 \\
$\begin{array}{l}\text { Shannon normalized } \\
\text { index }\end{array}$ & 0.717 & 0.729 & 0.473 & 0.680 & 0.734 \\
Simpson index & 0.937 & 0.944 & 0.866 & 0.939 & 0.930 \\
\hline
\end{tabular}

Da-09, Daugavpils in 2009; Da-10, Daugavpils in 2010; St-09, Stende in 2009; St-10, Stende in 2010; Pr-09, Priekuḷi in 2009

Table 7

KOSMAN'S ASSIGNMENT-BASED DISTANCE (KOSMAN, 1996) BETWEEN POPULATIONS OF Blumeria graminis f.sp. hordei IN LATVIA IN 2009-2010

\begin{tabular}{l|c|c|c|c|c}
\hline Populations & Da-10 & St-09 & St-10 & Pr-09 & 2010 \\
\hline Da-09 & 0.101 & 0.215 & 0.203 & 0.102 & \\
Da-10 & & 0.211 & 0.304 & 0.107 & \\
St-09 & & & 0.318 & 0.190 & \\
St-10 & & & & 0.193 & \\
2009 & & & & & 0.159
\end{tabular}

2009

Da-09, Daugavpils in 2009; Da-10, Daugavpils in 2010; St-09, Stende in 2009; St-10, Stende in 2010; Pr-09, Priekuḷi in 2009

In 2009-2010, virulence frequencies of Va6, Va7, Va9, $V a 12, V k$ and $V L a$ were similarly high in all locations. This is likely due to the lack of a geographic barrier, and a change in one location can spreads to other regions (Zhu et al., 2010). Genes Mla6, Mla7, Mla9, Mla12, Mlk and MlLa can be considered as typical unnecessary resistance genes in Latvia. These resistance genes, used in approximately 700 cultivars, were gradually overcome by new pathogen pathotypes in a period of four to five years in Europe (Czembor, 2000). Significant differences of virulence in the pathogen population between samples collected in different parts of Latvia were detected for Val, Va3 and Val3. Significantly lower frequencies of Val, Va3 and Val3 were detected in Stende in 2010. A clear tendency of increasing frequency of these genes was observed in some previous years in SouthEastern Latvia (Kokina and Rashal, 2004; Kokina and Rashal, 2005a; Kokina and Rashal, 2006; Kokina and Rashal, 2008). In many European countries, Val, Va3 and Val3 had moderate to high frequency approximately ten years ago (Hovmøller et al., 2000). Presently, these genes are still effective in Central and Eastern Asia, for example, in winter barley regions of China. Dreiseitl and Wang (2007) found no isolates that could overcome Mla1, Mla3, Mla13, Mla6, Mla7, Mla9, Mla12 and MlLa. Virulence frequencies of Mlk were very low. In the Zhu et al. (2010) study, no isolate was found to be virulent to Mla1, Mla3, Mla6, Mla9, Mla13 and the virulence frequency to Mla7, Mla12 and Mlk was very low.

In 2009-2010, a tendency of increasing $V(M e), V(S t)$ and $V(G o)$ frequency was observed. The presence of the these virulences in the Latvian population of the pathogen can be explained by the fact that the corresponding pathotypes spread from Western Europe, where increasing trends were detected in 2000 already (Hovmøller et al., 2000). It is quite possible that 'Steffi', 'Goldie' and 'Meltan' resistance genes will lose their effectiveness in the near future, but several resistance genes are still present in these varieties.

Mlo resistance does not correspond to a gene-for-gene system. Since 1979, the barley mlo gene has been defined as highly effective and Mlo resistance confers nearly total resistance against fungal penetration attempts. Cytological investigation has shown in Mlo genotypes the ability to form effective papillae at sites of attempted penetration (Jarosch et al., 2003). Presently, this resistance is still effective, and is the most used resistance in spring barley grown through- 
out Europe. In 2009-2010, this resistance was effective also in Latvia, and only some sporadic pustules of the pathogen were detected on the differential with mlo5.

Breeding for resistance is a cheap and environmentally safe approach to reduce loss in yield caused by powdery mildew of barley, which can reach $20 \%$ in Europe (Czembor, 2000). However, breeding for resistance depends on having gene pools from which new genes can be introduced into existing cultivars, and new none-specific resistance sources are needed. Barley line SII was considered as a new resistance source for the control of powdery mildew (Hovmøller et al., 2000). Not any isolate with virulence to SII was detected in Latvia in 2009-2010, as well asnor in previous years. Further observation of this virulence is necessary in Latvia and elsewhere in Europe.

According to Limpert (2008), for wind-dispersed nomadic diseases (including barley powdery mildew), although pathotypes are dispersed anywhere, predominantly dispersal in Europe is from West to East in the direction of prevailing winds. Complexity or the number of virulence genes per pathogen accumulate in this direction, because of migration and selection (Limpert and Bartoš, 2002). This is also apparent in Latvia, where the lowest complexities was observed in Stende, located in the Western part of Latvia. Mean complexity accumulates in the Eastern direction, shown by a higher level in Priekuli and even higher in Daugavpils.

In Daugavpils, the population of Blumeria graminis f.sp. hordei had particularly high diversity. In 1995, the pathotype al a3 al3 was detected in Latvia for the first time. In 2009-2010, this new and dangerous pathotype was found only in Daugavpils. This might be due to possible gene flow (spore migration from neighbouring Lithuania and Belarus). Also, in south-eastern Latvia, where Daugavpils is located, the climatic conditions are harsher, with lower winter temperatures. This might explain the favourable selection of new genotypes with possibly higher viability, but more vulnerable genotypes. Based on data presented here, it is possible to choose the best strategy for resistance breeding under Latvian conditions and to create new varieties with durable resistance.

\section{ACKNOWLEDGMENTS}

Authors are thankful to Dr. Māra Bleidere and Dr. Linda Legzdina for providing of pathogen samples.

\section{REFERENCES}

Anonymous (2009a). Ministry of Agriculture Republic of Latvia. Agriculture and Rural Area of Latvia. Available at http://www.zm.gov.lv/doc_upl/EN_Zinojums.pdf

Anonymous (2009b). FAO statistical databases (FAOSTAT). Available at http://faostat.fao.org/

Brown, J.K.M. (2003). Little else but parasites. Science, 229, 1680-1681.

Brown, J.K.M., Jørgensen, J.H. (1991). A catalogue of mildew resistance genes in European barley varieties. In: Proceedings of the Second Euro- pean Workshop on Integrated Control of Cereal Mildew. 23-25 January 1990, Roskilde (pp. 263-286). Roskilde: Risø National Laboratory.

Caffier, V., Brändle, U.E., Wolfe, M.S. (1999). Genotypic diversity in barley powdery mildew populations in northern France. Plant Pathol., 48, 582-587.

Czembor, J.H. (2000). Resistance to powdery mildew in barley (Hordeum vulgare L.) landraces from Egypt. Plant Gen. Res. Newslett., No. 123, pp. 52-60.

Czembor J.H. (2001). Sources of resistance to powdery mildew (Blumeria graminis f.sp. hordei) in Moroccan barley landraces. Can. J. Plant Pathol., 23, 260-269.

Dreiseitl, A. (1998). Comparison of methods to study powdery mildew and monitor the population of Erysiphe graminis f.sp. hordei in 1997. Plant Protect. Sci., 34, 33-38.

Dreiseitl, A. (2000). Direct selection in the Blumeria graminis f.sp. hordei population in Czech Republic. Phytopathology, 35, 317-322.

Dreiseitl, A. (2004a). Adaptation of biotrophic barley pathogens to genetic resistance in Central Europe. In: Barley Genetics IX, Proceedings of the $9^{\text {th }}$ International Barley Genetics Symposium. Vol. 1. Invited Papers. 20-26 June 2004, Brno, Czech Republic (pp. 243-248). Spunar, J., Janikova, J. (eds.). Brno.

Dreiseitl, A. (2004b). Virulence frequencies to powdery mildew resistance genes of winter barley cultivars. Plant Protect. Sci., 40, 135-140.

Dreiseitl, A., Wang, J. (2007). Virulence and diversity of Blumeria graminis f.sp. hordei in East China. Eur. J. Plant Pathol., 117, 357-368.

Dreiseitl, A. (2008). Virulence Frequency to powdery mildew resistances in winter barley cultivars. Czech. J. Genet. Plant Breed, 44(4), 160-166.

Dreiseitl, A., Dinoor, A., Kosman, E. (2006). Virulence and Diversity of Blumeria graminis f. sp. hordei in Israel and in the Czech Republic. Plant Dis., 90,1031-1038.

Hovmøller, M., Caffier, V., Jalli, M., Andersen, O., Besenhofer, G., Czembor, J., Dreiseitl, A., Felsenstein, F., Fleck, A., Heinrics, F., Jonsson, R., Limpert, E., Mercerr, P., Plesnik, S., Rashal, I., Skinnes, S., Vronska, O. (2000). The European barley powdery mildew virulence survey and disease nursery 1993-1999. Agronomy, 20, 729-743.

Jarosch, B, Jansen, M, Schaffrath, U. (2003). Acquired resistance functions in mlo barley, which is hypersusceptible to Magnaporthe grisea. Mol. Plant Microbe Interact., 16(2), 107-114.

Jørgensen, J.H. (1992). Discovery, characterization and exploitation of Mlo powdery mildew resistance in barley. Euphytica, 63, 141-152.

Kokina, I., Rashal, I. (2004). Genetical structure of the population of Blumeria graminis f. sp. hordei in Latgale region of Latvia in 2001-2002. Acta Biol. Univ. Daugavpiliensis, 4(2) 65-70.

Kokina, I., Rashal, I. (2005a). Pathotypes of barley powdery mildew fungus (Blumeria graminis f.sp. hordei) in the Latgale region of Latvia in 1996-2000. Proc. Latv. Acad. Sci., Section B, 59(3/4), 151-155.

Kokina, I., Rashal, I. (2005b). Trends of changes of genetic structure of the population of Blumeria graminis $\mathrm{f}$. sp. hordei in the Latgale region of Latvia in 2003-2004. Acta Biologica Universitatis Daugavpiliensis, 5(2), 187-192.

Kokina I., Rashal I. (2006). Monitoring the population of Blumeria graminis f. sp. hordei in the South-Eastern part of Latvia. Agron. Res., 4, 231-236.

Kokina, I., Rashal, I. (2008). Results of the monitoring of the population of Blumeria graminis f.sp. hordei in the Latgale region of Latvia in 2007. Zemdirbyste-Agriculture, 95(3), 320-326.

Kokina, I., Statkeviciute, G., Leistrumaite, G., Rashal, I. (2012). Genetic structure pecularities of the Blumeria graminis f.sp. hordei population in Lithuania in 2010. Zemdirbyste-Agriculture (in press).

Kosman, E. (1996). Difference and diversity of plant pathogen populations. A new approach for measuring. Phytopathology, 86, 1152-1155.

Kosman, E. (2002). Koind-package of programs for calculating diversities within populations, distances between populations and measure of gene linkage. Petria, 12, 249-252. 
Kosman E., Leonard K. (2007). Conceptual analysis of methods applied to assessment of diversity within and distance between populations with asexual or mixed mode of reproduction. New Phytopatologist, 174, 683-696.

Kølster, P., L. Munk, O. Stųlen, Lohde, J. (1986). Near isogenic barley lines with genes for resistance to powdery mildew. Crop Sci., 26, 903-907.

Laine, A.L. (2006). Evolution of host resistance: Looking for coevolutionary hotspots at small spatial scales. Proc. R. Soc., 273, 267-273.

Limpert, E. (1996). Conclusions and hypothesis from investigating cereal mildew pathogens at grand scale. In: Integrated Control of Cereal Mildews and Rusts: Towards coordination of research across Europe. COST 817 Population Studies of Airborne Pathogens on Cereals as a Means of Improving Strategies for Disease Control (pp. 33-37). Finckh, M., Wolfe, M (eds.). Office for Official Publications of the European Communities, Luxembourg.

Limpert, E. (2008). Effects of wind dispersal on pathogen populations spread across Europe and Eurasia. AirPath - Meeting, University College London, 6th-7th November, 2008.

Limpert, E., Bartoš, P. (2002). Wind-Dispersed Nomadic Diseases: Conclusions for Disease Resistance. Czech J. Genet. Plant Breed., 38(3-4), $150-152$

McDermott, J.M., Brändle, U., Dutly, F., Haemmerli, U.A., Keller, S., Müller, K.E., Wolfe, M.S. (1994). Genetic variation in powdery mildew of barley: Development of RAPD, SCAR, and VNTR Markers. Phytopathology, 84(11), 1316-1321.

Müller, K., McDermott, J.M., Wolfe, M.S., Limpert, E. (1996). Analysis of diversity in populations of plant pathogens: The barley powdery mildew pathogen across Europe. Eur. J. Plant Pathol., 102, 385-395.

Piffanelli, P., Ramsay, L., Waugh, R., Benabdelmouna, A., D’Hont, A., Hollrocher, K., Jørgensen, J.H., Schulze-Lefert, P., Panstruga, R. (2004). A barley cultivation-associated polymorphism conveys resistance to powdery mildew. Nature, 430, 887-891.

Rashal, I., Tueryapina, R. (1996). Barley powdery mildew in Latvia: Genetic structure of the pathogen population. In: Integrated Control of Cereal Mildews and Rusts: Towards Coordination of Research Across Europe. Limpert, E., Finckh, M.R., Wolfe, M.S. (eds.). European Commission Directorate General XII - Science, Research, Development. Brussels, Luxembourg (pp.15-19).

Tueryapina, R., Jensen, H.P., Rashal, I. (2007). Powdery mildew resistance genes in Baltic spring barley varieties and breeding lines. Barley Gen. Newslett., 27, 18-21.

Richter, T.E., Ronald, P.C. (2000). The evolution of disease resistance genes. Plant Mol. Biol., 42, 195-204.

Sacristán. S., Garcia-Arenal. F. (2008). The evolution of virulence and pathogenicity in plant pathogen populations. Mol. Plant Pathol., 9(3), 369-384.

Schüller, C., Backes, G., Fischbeck, G., Jahoor, A. (1992). RFLP markers to identify the alleles on the Mla locus conferring powdery mildew resistance in barley. Theor. Appl. Gen.., 84, 330-338.

Thrall, P., Burdon, J.J. (2003). Evolution of virulence in a plant host-pathogen metapopulation. Science, 299, 1735-1737.

Torp, J., Jensen, H.P., Jørgensen, J.H. (1978). Powdery mildew resistance genes in 106 Northwest European spring barley varieties. Kgl. Vet.-og. Landbohejsk. Arsskr., 75-102.

Zhu, J.H., Wang, J.M., Jia, Q.J., Yang, J.M., Zhou, Y.J., Lin, F., Hua, W., Shang, Y. (2010). Pathotypes and genetic diversity of Blumeria graminis f.sp. hordei in the winter marley regions in China. Agric. Sci. China, 9(12), 1787-1798.

Received 1 July 2011

\section{MIEŽU MILTRASAS IZSRAISĪTĀJA Blumeria graminis f.sp. hordei POPULĀCIJAS MONITORINGS LATVIJĀ, 2009-2010}

Miežu miltrasas izraisītāja paraugi tika ievākti 2009.-2010. gadā. Daugavpils apkārtnē (Latgale), Stendē (Kurzeme) un Priekuḷos (Vidzeme). Katrā populācijā noteiktas patogēna virulences gēnu frekvences, virulences gēnu skaits katram individuālajam izolātam un patotipi. Ievērojamas frekvenču atšķirības starp populācijām konstatētas virulences gēniem Val, Va3 un Va13. Populāciju raksturojošie rādītāji (Neja, Millera, Kosmana, Šenona un Simpsona indeksi) liecina par ievērojamu daudzveidības palielināšanos Latgalē un Kurzemē pētījuma laikā. Daugavpils apkārtnē ievāktajiem paraugiem tika konstatēta īpaši liela patotipu daudzveidība. 